\title{
Fringe benefits and organizational commitment: the case of Langkawi hotels
}

\begin{abstract}
This paper examines the relationship between the characteristics of hotel compensation systems and managers’ organizational commitment. Managerial compensation is a critical area influencing hotel performance but few studies have been published of compensation in the Malaysian hotel industry in relation to organisational commitment. In this study, compensation was evaluated on four dimensions: external competitiveness (EC), compensation based on performance (CBP), incentive-base $\operatorname{mix}$ (IBM) and openness and participation (OP). Organisational commitment was measured on three dimensions: affective commitment (AC), continuous commitment (CM) and normative commitment (CM). A total of 250 questionnaires were distributed to three, four and five-star hotel managers in Langkawi Island with a response rate of $42 \%$. The findings revealed that all four dimensions of a compensation system were positively related to managers’ organisational commitment. The significance of these findings is discussed.
\end{abstract}

Keywords: Compensation, Strategic human resource management, Hotel, Organizational commitment, Malaysia

\section{Introduction}

Organizational commitment is a key factor in the service sector (Gjerald and Ogaard, 2010; He, Murmann and Perdue, 2012; Lee et al., 2012). Studies have found a negative relationship between organizational commitment and costly behaviour such as absenteeism, turnover intention and 
turnover (Hemdi and Nasurdin, 2006; Lee et al., 2012; Smith et al., 1996; Sun et al., 2007; Walsh and Taylor, 2007). Increased commitment can enhance the quality of work, productivity, service quality and organizational cohesiveness (Lee et al., 2012; Smith et al., 1996).

Fair and attractive compensation is one of the factors that have been found to increase organisational commitment (He et al., 2012; Lee et al., 2012; Walsh and Taylor, 2007). The importance of compensation is noted in a number of empirical studies. Compensation drives organization competitiveness by increasing an employee's performance, initiative, and engagement with the organisation (Danish and Usman, 2010; Resurreccion, 2012). Compensation practices in the hotel industry are diverse and complex (Ahmad et al., 2010; Hooi, 2006). Empirical studies have shown that hotels usually have more than one compensation policy (Ahmad et al., 2010; Hooi, 2006). However, very few studies have found that hotels integrate these policies into a strategic compensation system (Lee et al., 1995). This study examines the relationship between components of hotel compensation systems and organisational commitment to identify which factors affect organizational commitment.

\section{Literature Review}

A compensation system includes four major components: external competitiveness (EC), compensation based on performance (CBP), incentive-base mix (IBM) and openness and participation (OP) (Lee et al., 1995; Montemayor, 1996). These four components of compensation systems are frequently used by large firms in developing their HR policies (Ahmad et al., 2010; Gomez-Mejia, 1992) and are often discussed in the strategic compensation literature (Lee et al., 1995; Montemayor, 1996). 
Compensation of employees with pay and fringe benefits better than the competitors (EC) (Montemayor, 1996; Gomez- Mejia, 1992; Kline and Yu-Chin, 2007) is an effective strategy frequently used - especially in a tight labour market - by large full service hotels to acquire experienced, skilled and competent staff (Kline and Yu-Chin, 2007; Nankervis, 2000). A second component (CBP) is defined as pay and benefits awarded to employees based on their performance and contribution to the organization's profitability (Perry, Engbers and So, 2009). Among its benefit are increased workers’ productivity, effort and earnings (Green and Heywood, 2007). However, CBP has been criticised for weaknesses such as favouritism (Perry et al., 2009; Ahmad et al., 2010) and disproportionate wage differences among employees (Green and Heywood, 2007; Lemieux et al., 2009). Incentive-base mix (IBM) refers to the mixture of variable and fixed pay and whether the incentive component depends on firm's performance (Gerhart and Trevor, 1996; Montemayor, 1996). Previous research has not examined if the mixture of fixed with variable pay enhances positive behaviour such as organisational commitment. Compensation openness and performance (OP) refers to openness in providing employees with information about their compensation and giving them the authority to participate and question pay decision (GomezMejia, 1992; Montemayor, 1996). Gomez-Mejia (1992) and Montemayor (1996) suggest that OP lowers operational costs, reduces bureaucracy, increases flexibility and enhances employees’ job satisfaction.

Organizational commitment is defined as a force that binds an individual to a course of action that is of relevance to the organization's target (Meyer and Herscovitch, 2001). From a psychological perspective, organizational commitment can be separated into affective, continuance and 
normative components (Meyer and Allen, 1997). Affective commitment (AC) is the emotional desire to be attached to the organization due to the feeling of comfort and personal competence, continuance commitment (CC) is the need to be with the organization because of the costs associated with leaving the organization and normative commitment (NC) is the obligation to stay with the organization due to loyalty norm. The three components of organizational commitment influence the employee's behavioural outcome in the organization differently. Affective commitment (AC), the component with the strongest effect on positive work behavioural outcome is positively related to job performance, organizational loyalty and citizenship (Meyer et al., 1989;

Shore and Wayne, 1993; Wright et al., 2003). Continuance commitment (CC) and normative commitment (NC) reduced employee turnover (Meyer et al., 1989).

\section{Method}

The relationship between compensation system practices and managerial employees’ organisational commitment was tested in a sample of hotel managers from three, four and five-star hotels in Langkawi, Malaysia. A co-relational design with quantitative data collection was utilised. A self-administered questionnaire was used to collect data from the research sample. Questionnaires were distributed with the help of the hotels' human resource manager. Out of 250 questionnaires distributed, 104 were returned (response rate of 42\%). The percentage of the questionnaires returned from the three, four and five-star hotels was 28\%, 51\% and 21\% respectively.

The scale used to measure hotel's use of compensation system components for managerial employees has 18 items that are rated using a 7-point numerical scale ranging from "never" to 
“apply completely". Some of the items were developed based on Ahmad et al. (2010) findings while others are adapted from Gomez-Mejia (1992). This study used the organisation commitment scale from Meyer and Allen (1997) which is divided into three components; AC, CC and NC. Managerial employees were asked to rate their organisation ranging from "totally disagree" to “totally agree” using a 7-point numerical scale. Cronbach’s alpha was used to examine the internal consistency and the reliability of the instrument and Spearman's rho correlation coefficients were used to determine the magnitude of the relationships between each of the variables. Spearman's rho was used instead of Pearson's correlation because the requirement for using parametric tests was not met.

\section{Results}

The overall Cronbach's alpha value for all compensation system attributes of 0.903 indicates a strong internal consistency among the attributes. A significant positive relationship was found between compensation system components and organisational commitment: CBP $(\rho=0.772$, $\mathrm{p}=0.000)$ and EC $(\rho=0.734, p=0.000)$ components showed a significant and strong positive correlation with AC. IBM had a moderate correlation with AC ( $\rho=0.407, p=0.000)$, NC $(\rho=0.426$, $\mathrm{p}=0.000$ ) and total organisational commitment $(\rho=0.426, \mathrm{p}=0.000)$. There was a weak relationship between OP and AC $(\rho=0.364, p=0.000)$ and total organisational commitment $(\rho=0.358, p=0.000)$. The relation between OP with NC was not significant. The Spearman's rho for compensation system and organisational commitment relationships is displayed in Table 1.

Table 1: Correlation Test on Compensation System and Organisational Commitment

\begin{tabular}{lllcc}
\hline $\begin{array}{l}\text { Compensation } \\
\text { System }\end{array}$ & AC & CC & NC & $\begin{array}{c}\text { Organisational } \\
\text { Commitment }\end{array}$ \\
\hline
\end{tabular}




\begin{tabular}{|l|c|c|c|c|c|c|r|r|r|}
\hline \multicolumn{1}{l}{} & Corr. & Sig. & \multicolumn{1}{c}{ Corr. } & \multicolumn{1}{c}{ Sig. } & \multicolumn{1}{l}{ Corr. } & Sig. & \multicolumn{1}{c}{ Corr. } & \multicolumn{1}{c}{ Sig. } \\
\hline $\begin{array}{l}\text { Total Compensation } \\
\text { System }\end{array}$ & 0.715 & 0.000 & 0.451 & 0.000 & 0.649 & 0.000 & 0.670 & 0.000 \\
\hline EC & & & & & & & & \\
\hline CBP & 0.734 & 0.000 & 0.543 & 0.000 & 0.650 & 0.000 & 0.693 & 0.000 \\
\hline IBM & 0.772 & 0.000 & 0.527 & 0.000 & 0.638 & 0.000 & 0.714 & 0.000 \\
\hline OP & 0.407 & 0.000 & 0.308 & 0.001 & 0.426 & 0.000 & 0.426 & 0.000 \\
\hline
\end{tabular}

\section{Discussion and Conclusions}

This study has found a significant and positive relationship between compensation system and organisational commitment. Out of four dimensions, two dimensions, CBP and EC showed a strong and positive correlation with AC. Although the strength was quite weak, IBM and OP were also significantly and positively related to the positive behavioural outcome. There is consensus on the importance of EC in improving OC (Montemayor, 1996; Gomez- Mejia, 1992; Kline and Yu-Chin, 2007) and this study has provided evidence of its importance to enhance hotel managers' OC. The findings of this study provide support to the importance of CBP, an area of ongoing debate. Despite the concerns about favouritism and inappropriate salary differences (Ahmad et al., 2010; Green and Heywood, 2007; Lemieux et al., 2009), the significance of CBP in Langkawi hotels is evident. Specifically, results support the notion that CBP is effective for higher level jobs subject to low levels of supervision (Mahoney, 1989).

Relationships between OC and IBM were significant and positive, between OC and both AC and NC were they were moderate and between OC and CC relationships were weak. A main use of IBM is to reduce an organisation's fixed costs and pay employees more when the organisation is in a better financial position (Gerhart and Trevor, 1996). Therefore, even though the positive relationship with OC was not strong, it is crucial for organisation's survival. The OP dimension had the weakest relationship with OC. 
In summary, the compensation system practices applied to hotel managers appear to improve OC. In order to retain high performing managers, it is crucial for hotels to compensate their managerial employees better than the competitors and based on individual performance. The use a mix of fixed and variable pay, and involving employees in compensation decisions is also effective but IBM and OP components do not enhance significantly OC in this study.

This research has found a significant positive relationship between hotel compensation systems and managerial employees OC. This study extends the knowledge of compensation in the hotel industry, in particular, the Malaysian hotel industry. The need to provide further information of compensation practices and OC has been highlighted in the human resource management literature (Ahmad et al., 2010; Ibrahim and Boerhaneoddin, 2010). Furthermore, OC is an attitude which is stable and long termed (Porter et al., 1974) so a better understanding of the drivers of OC may allow more effective prediction of organisational performance. The findings of this study benefit the decision makers by providing information on the compensation practices of the industry in Langkawi.

This study has several limitations which should be addressed in further research Firstly, nonparametric tests was used as the data was not normally distributed. Further research should seek to use more powerful parametric tests. Secondly, the response rate at less than half of the research sample is low. Finally, the findings of this research are limited to Langkawi Island in Malaysia and further research in a larger hotel industry context would be beneficial. 


\section{References}

Ahmad, R., Scott, N., Solnet, D., 2010.The practise of strategic compensation in Malaysian fivestar beach resort hotels. In: Ismail, D., Yahya, M.A., Zalazilah, M.H., Jaafar, M.K., Yaakob, A. and Kamil, S., Entrepreneurship and Societal Development in Asean: “Achieving regional growth through entrepreneurship.” Proceedings of the $1^{\text {st }}$ International Seminar for ASEAN Universities Consortium on Entrepreneurship Education, AUCEE Seminar, Langkawi, Malaysia.

Danish, R.Q., Usman, A., 2010. Impact of reward and recognition on job satisfaction and motivation: An empirical study from Pakistan. International Journal of Business and Management 5 (2), 159-167.

Gerhart, B., Trevor, C.O., 1996. Employment variability under different managerial compensation systems. Academy of Management Journal 39 (6), 1692-1712.

Gjerald, O., Ogaard, T., 2010. Exploring the measurement of basic assumptions about guests and co-workers in the hospitality industry. International Journal of Contemporary Hospitality Management 22 (6), 887-909.

Gomez-Mejia, L.R., 1992. Structure and process of diversification, compensation strategy and firm performance. Strategic Management Journal 13 (5), 381-397. 
Green, C., Heywood, J.S., 2007. Does performance pay increase job satisfaction? Economica 75, $710-728$.

He, P., Murmann, S.K., Perdue, R.R., 2012. Management commitment and employee perceived service quality: The mediating role of affective commitment. The Journal of Applied Management and Entrepreneurship 17 (3), 79-97.

Hemdi, M. A., Nasurdin, A. M., 2006. Predicting turnover intentions of hotel employees: The influence of employee development, human resource management practices and trust in organisation. GadjahMada International Journal of Business 8 (1), 21-42.

Hooi, L.W., 2006. Japanese remuneration systems in Malaysia: A case study analysis. Compensation and benefits review 38 (31), 31-41.

Ibrahim, I.I., Boerhaneoddin, A., 2010. Is job satisfaction mediating the relationship between compensation structure and organisational commitment? A study in the Malaysian power utility. Journal of Global Business and Economics 1 (1), 43-61.

Kline, S., Yu-Chin, H., 2007. Wage differentials in the lodging industry: A case study. Journal of Human Resources in Hospitality and Tourism 6 (1), 69-84. 
Lee, D.C., Hung, L.M., Chen, M.L., 2012. Empirical study on the influence among corporate sponsorship, organisational commitment, organisational cohesiveness and turnover intention. Journal of Management and Sustainability 2 (2), 43-53.

Lee, M.B., Scarpello, V., Rockmore, B.W., 1995. Strategic compensation in South Korea's publicly traded firms. The International Journal of Human Resource Management 6 (3), 686-701.

Lemieux, T., MacLeod, W.B., Parent, D., 2009. Performance pay and wage inequality. The Quarterly Journal of Economics 124 (1), 1-49.

Mahoney, T.A., 1989. Multiple pay contingencies: Strategic design of compensation. Human Resource Management 28, 337-347.

Meyer, J. P., Paunonen, S. V., Gellatly, I. R., Goffin, R. D., Jackson, D. N., 1989. Organizational commitment and job performance: It's the nature of the commitment that counts. Journal of Applied Psychology 74 (1), 152-156.

Meyer, J. P., Herscovitch, L., 2001. Commitment in the workplace: Toward a general model. Human Resource Management Review 11, 299-326.

Montemayor, E. F., 1996. Congruence between pay policy and competitive strategy in high performing firms. Journal of management 22 (6), 889-908. 
Nankervis, A., 2000. Human resource management strategies as competitive advantage: A case example of the hospitality sector in Southeast Asia and the Pacific Rim. Research and Practice in Human Resource Management 8 (1), 111-133.

Perry, J.L., Engbers, T.A., So, Y.J., 2009. Back to the future? Performance-related pay, empirical research, and the perils of persistence. Public Administration Review 69 (1), 39-51.

Porter, L. W., Steers, R. M., Mowday, R. T., Boulian, P. V., 1974. Organizational commitment, job satisfaction, and turnover among psychiatric technicians. Journal of Applied Psychology 59 (5), 603-609.

Resurreccion, P.F., 2012. Performance management and compensation as drivers of organization competitiveness: The Philippine perspective. International Journal of Business and Social Science 3 (21), 20-30.

Shore, L. M., Wayne, S. J., 1993. Commitment and employee behaviour: Comparison of affective commitment and continuance commitment with perceived organizational support. Journal of Applied Psychology 78 (5), 774-780.

Smith, K., Gregory, S.R., Cannon, D., 1996. Becoming an employer of choice: Assessing commitment in the hospitality workplace. International Journal of Contemporary Hospitality Management 8 (6), 3-9. 
Sun, L. Y., Aryee, S., Law, K. S., 2007. High performance human resource practices, citizenship behaviour, and organisational performance: A relational perspective. Academy of Management Journal 50 (3), 558-577.

Walsh, K., Taylor, M.S., 2007. Developing in-house careers and retaining management talent: What hospitality professionals want from their jobs? Cornell Hospitality Quarterly 48 (2), 163-182.

Wright, P. M., Gardner, T. M., Moynihan, L. M., 2003. The impact of HR practices on the performance of business units. Human Resource Management Journal 13 (3), 21-36. 